\title{
Development of Pocket Book of Character Education Of Nautical Admiral Hang Tuah Based on Pancasila Education and Citizenship
}

\author{
Aris Saputro ${ }^{1)}$, Sri Untari ${ }^{2)}$, Nuruddin Hady ${ }^{3)}$ \\ 1, 2,3) Department of Pancasila and Citizenship Education, Faculty of Science \\ State, University of Malang, Indonesia \\ Corresponding Author: Aris Saputro,Email: arissaputro476@gmail.com
}

\begin{abstract}
History: Received 09/01/2021 | Revised 08/01/2021 | Accepted 18/01/2021 | Published 31/01/2022
Abstract. History that tells related to the Indonesian nation has been a maritime nation since long ago, including known from the history of Srivijaya and Majapahit and the famous figure of Admiral Hang Tuah. This article aims to introduce and understand the values of the educational character of the VATbased Admiral Hang Tuah. Pocket books are small, light, and practical books containing essential and interesting information (material). The religious character education pocket book contains much information related to strengthening character education, archipelago insight, nautical culture, and character values of Admiral Hang Tuah. This type of research is the development research of the ADDIE model. The results of the discussion, first, the development of the pocket book of the character of Admiral Hang Tuah consists of five stages of development: analysis, design, development, implementation, and evaluation. Second, the feasibility of the media pocket book of character education of the character of Admiral Hang Tuah contains three things: the feasibility of the content of the book, the feasibility of language, and the feasibility of the media. Based on the overall results of the pocket book assessment, material experts, linguists, and media experts obtained a score of 4.4, with a very decent category. Based on the response of students of class VII A Junior High School Hang Tuah 4 Surabaya with a pocket book shows an average score of 4.6 , which belongs to the category is very feasible. The conclusion of the development of pocket book media education of the character of the kebaharian Admiral Hang Tuah through five stages and the feasibility of pocket book media are based on the assessment of material experts, linguists, and media experts as well as the student's response to the pocket book of the character of the nautical.
\end{abstract}

Keywords: Pocket Book; Character Education; Nautical; Admiral Hang Tuah; Pancasila Education and Citizenship

\begin{abstract}
Abstrak. Sejarah yang menceritakan terkait bangsa Indonesia telah menjadi bangsa bahari semenjak dahulu, di antaranya diketahui dari sejarah Sriwijaya dan Majapahit serta terkenalnya tokoh Laksamana Hang Tuah. Tujuan dari penulisan artikel ini adalah mengenalkan dan memahami nilai-nilai pendidikan karakter kebaharian Laksamana Hang Tuah Berbasis PPKn. Buku saku merupakan buku yang berukuran kecil, ringan, dan praktis yang berisi suatu informasi (materi) penting serta menarik. Buku saku pendidikan karakter kebaharian memuat banyak hal informasi terkait penguatan pendidikan karakter, wawasan nusantara, budaya bahari, dan nilai-nilai karakter Laksamana Hang Tuah. Jenis penelitian ini adalah penelitian pengembangan model ADDIE. Hasil pembahasan, pertama, pengembangan buku saku karakter kebaharian Laksaman Hang Tuah terdiri dari lima tahap pengembangan yaitu: analisis, perancangan, pengembangan, implementasi, dan evaluasi. Kedua, kelayakan media buku saku pendidikan karakter kebaharian Laksamana Hang Tuah memuat tiga hal yaitu kelayakan isi buku, kelayakan kebahasaan, dan kelayakan media. Berdasarkan hasil keseluruhan penilaian buku saku berdasarkan ahli materi, ahli bahasa, dan ahli media memperoleh skor 4,4 dengan kategori sangat layak. Berdasarkan respon siswa kelas VII A SMP Hang Tuah 4 Surabaya dengan adanya buku saku menunjukkan skor rata-rata sebesar 4,6 yang termasuk kategori sangat layak. Kesimpulan pengembangan media buku saku pendidikan karakter kebaharian Laksamana Hang Tuah melalui lima tahap dan kelayakan media buku saku didasarkan pada penilaian dari ahli materi, ahli bahasa, dan ahli media serta respon siswa terhadap buku saku karakter kebaharian
\end{abstract}

Kata Kunci: Buku Saku; Pendidikan Karakter; Kebaharian; Laksamana Hang Tuah; Pendidikan Pancasila dan Kewarganegaraan 


\section{INTRODUCTION}

Education is a process of mutual adjustment carried out by humans, be it with nature, fellow human beings, or the development and refinement done regularly from all the potentials he has. These potentials include the moral, intellectual, and physical potential of man. This potential is in line with the National Education Objective in Indonesia as stated in Law No. 20 of 2003 on the National Education System, namely being a person who believes and fear God Almighty, noble, healthy, knowledgeable, capable, creative, independent, democratic and responsible (Acetylena, 2018).

Character education is a conscious effort made by humans to instill and develop the values of goodness to humanize humans, improve character, and train intellectual students to create a generation of knowledge and character that can provide benefits of knowledge for the surroundings (Sofyan, 2017). The purpose of character education is the formation of student ethics on every track, type, and level of education to live and practice the noble values of the Indonesian nation. The primary way to shape human resources into quality, character, faith, and pancasilaist spirit can only be realized by education and strengthening character education in the nation's next generation.

Strengthening character education on human resources can not be separated from the history that tells the Indonesian nation is maritime.

Known from the history of Srivijaya and Majapahit. Srivijaya is a maritime kingdom that stands on the island of Sumatra and exerts a lot of influence in the archipelago with areas of power that stretch from Cambodia, Southern Thailand, Malay Peninsula, Sumatra, West Java to parts of Central Java. The kingdom was established from 671 AD to 1183 $\mathrm{AD}$ and managed to control maritime trade routes in Malacca, Sunda Strait, South China Sea, the Java Sea, to Karimata Strait. The kingdom of Srivijaya became a maritimebased kingdom (Yani and Montratama, 2018). The Majapahit Kingdom was a kingdom centered in East Java that once stood from about $1293 \mathrm{AD}$ to $1500 \mathrm{AD}$; this kingdom reached its peak by controlling a large area in the archipelago during the reign of Hayam Wuruk, who ruled in $1350 \mathrm{AD}$ to $1389 \mathrm{AD}$ Majapahit's jurisdiction includes Sumatra, Malay Peninsula, Kalimantan, Sulawesi. Nusa Tenggara Islands, Maluku, parts of Western Papua, Tumasik (Singapore), and Philippine Islands. The Canggu inscription, numbered $1358 \mathrm{AD}$, mentions 78 crossing points in the form of boat crossings in the country (Mandala Java), as a result of this proving also a maritime-based kingdom (Ricklefs, 2005).

According to President Jokowi, the development of the marine sector is the focus of Indonesia in the 21 st century. It emphasizes the five pillars: maritime culture and 
rebuilding Indonesia's maritime culture by redefining Indonesia's national identity as a maritime country (Yani and Montratama, 2018). This is also in line with the concept of ideals conveyed by Joko Widodo during his inauguration speech as President of the State of Indonesia that will make Indonesia a world maritime axis. Even at the East Asia Summit Forum (East Asia Summit) In Naypidaw, Myanmar, November 13, 2014, President Jokowi conveyed the concept of the marine sector referred to as the World Maritime Axis (PMD) if in English it is called Global Maritime Nexus (GMN).

The problems facing the Indonesian nation now, especially about character education in the younger generation of Indonesia, began to shift values to grow into individuals far from the idealized character to have as the nation's successor. In general, the main actors of these polemic problems are the younger generation and the generation that has passed through the situation of the younger generation itself, examples: individualism, hedonism, corruption, drugs, terrorism, and others. The above problems show that the application of character education in the world of education until this moment has not been able to show significant results, as intended in the purpose of national education itself. The Indonesian Ministry of Education, Culture, and Research and Technology recently carried out the Pancasila student profile program to strengthen the role of character education implementation to shape the character of the nation's generation in the future better.

Education is a process of mutual adjustment carried out by humans, be it with nature, fellow human beings, or the development and refinement done regularly from all the potentials he has. These potentials include the moral, intellectual and physical potential of man. This potential is in line with the National Education Objective in Indonesia as stated in Law No. 20 of 2003 on the National Education System, namely being a person who believes and fear God Almighty, noble, healthy, knowledgeable, capable, creative, independent, democratic and responsible (Acetylena, 2018).

Creativity and independence is the thing contained in the purpose of education and is a need in developing the importance of education to be interesting. That characteroriented education is needed today, especially to build values and mental attitudes that adopt the values of the nation's character in the younger generation and prevent the negative influence of globalization. Departing from the younger generation, the nation's next generation of hopes. The role of the younger generation is very influential on the future nautical of the Indonesian nation in the future.

So, the development of innovative and exciting needs such as pocket books to facilitate light reading for students is absolute. If the Indonesian nation has a broken young generation, then the Indonesian nation will 
slowly go to the gate of destruction and vice versa; if the nation has an excellent young generation, then the nation will continue to succeed in the global record.

The generation of the nation of character requires strengthening targeted educational materials such as strengthening the lessons of Pancasila Education and Citizenship (PPKn). VAT subjects are essential subjects for educating morals and being human. Therefore, in capturing this opportunity, a research study was conducted in the middle school environment hang Tuah 4 Surabaya, which is to develop the media of character education that is the target of PPKn subjects by developing a simple, engaging, and able to be a basic guideline for mastery of children to know, and is expected to be able to implement the value of the character of Admiral Hang Tuah in real life.

Previous research studies have been conducted by Zulfikar Waliyuddin Fattah related to the condition of the Pancasila Education learning process through a process where students are often bored with PPKn lessons. Learners prefer other lessons outside Pancasila education because they consider VAT an unimportant and uninteresting lesson and learn using conventional learning models (Fattah, 2020).

Departing from the presentation of innovations in the development of the pocket book of the character of Admiral Hang Tuah developed based on the subject of PPKn. Then, the author will spell out-thought by comprehensively discussing this article with the title of writing "Development of Pocket book of Character Education Of Nautical Admiral Hang Tuah Based on Pancasila Education and Citizenship."

\section{RESEARCH METHODS}

The method used to solve this research problem is to use the research method of developing the ADDIE model.

A development model is a research method used to produce a particular product and test its effectiveness (Sugiyono, 2015).

The development of the ADDIE model consists of 5 (five) significant phases or stages: analysis, design, development, implementation, and evaluation (Bakhri, 2019).

This research was designed as research Research and Development ( $\&$ \& $\& D$ ) with the characteristics of the ADDIE version development model characteristics. The ADDIE model is one of the most used models in instructional design and a guide to producing a practical design. Instructional design can also be known as learning technology. This means systematic processes that can help create and develop valuable, interesting, efficient teaching materials in an environment that supports the use of art, science, learning, and instructional theory (Aldoobie, 2015). 
Data Collection Techniques in this study used a sample of data subjects of 15 students of class VII A Junior High School Hang Tuah 4 Surabaya and assessments from Material Experts, Linguists, and Media Experts who are Teachers and Lecturers who are experts in their fields.

Data Analysis technique is after the data that has been collected from the data source will be calculated with the formula calculating the average value of the score of each indicator using the formula for eligibility assessment, as follows:

$$
\overline{\mathrm{x}}=\frac{\sum \mathrm{X}}{\mathrm{N}}
$$

Information:

$$
\begin{array}{ll}
\overline{\mathrm{X}} & =\text { average score } \\
\sum \mathrm{X} & =\text { number of scores } \\
\mathrm{N} & =\text { number of test subjects }
\end{array}
$$

Table 1. Assessment Criteria

\begin{tabular}{|c|c|}
\hline $\begin{array}{c}\text { Average } \\
\text { Score }\end{array}$ & $\begin{array}{c}\text { Eligibility Assessment } \\
\text { Criteria }\end{array}$ \\
\hline$\geq 4,2 \mathrm{~s} / \mathrm{d} 5,0$ & Very Worthy \\
\hline$\geq 3,4 \mathrm{~s} / \mathrm{d} 4,2$ & Proper \\
\hline$\geq 2,6 \mathrm{~s} / \mathrm{d} 3,4$ & Enough \\
\hline$\geq 1,8 \mathrm{~s} / \mathrm{d} 2,6$ & Less \\
\hline $1,0 \mathrm{~s} / \mathrm{d} 1,8$ & Very Lacking \\
\hline
\end{tabular}

This research will be developed and feasible if the average score is obtained $\geq 3.4$.

\section{DISCUSSION}

Based on the problems and results of existing research, it will be discussed related to the development of laksaman Hang Tuah character education pocket book based on PPKn and the feasibility of the family character education pocket book Admiral Hang Tuah.

\section{Development of Pocket Book of Character} Education Of The Nautical Admiral Hang

\section{Tuah Based on PPKn}

Development attempts to improve technical, theoretical, conceptual, and moral abilities according to needs through education and practice. Development is a process of designing learning logically and systematically to establish everything that will be implemented in the learning activities about the potential and competence of learners.

Pocket books are books of small size, light, can be carried and read (Husain, 2015). A pocket book is a small book that can be stored in your pocket and easily carried everywhere (Pusat Bahasa, 2016). A pocket book is a small book containing information that can be stored in the pocket to facilitate learners learning the material under any circumstances because the book can be carried everywhere (Setyono, 2012).

Pocket books are small, light, and practical books containing information that can be carried anywhere and read at any time by the owner. There are pocket books on the market, there are books that are presented interesting with various colors and pictures, but there are also pocket books that are only formal writing (Husain, 2015). So through the pocket book, learners can get information without wasting time to know the core and 
information. Based on the description above, it can be concluded that a pocket book is a small, light, and practical book that contains information (material) in the form of short readings and pictures and can be taken anywhere and can be read at any time by the owner.

Character Education is a systematic effort to instill and simultaneously develop consistently and continuously the qualities of character based on the state's religious values, culture, and philosophy that learners internalize at home, in school, and in society in their daily lives will shape character behavior. Character is a characteristic of distinguishing qualities between individuals (Purnamasari and Wangid, 2016).

Character education is the entire relational dynamic between individuals with various dimensions, both within and outside (Zainal, 2011). So if drawn in the realm of education as described by Peterson, namely "Character education is a broad term that is used to describe the general curriculum and organizational features of schools that promote the development of fundamental values in children at school," Character education is a broad term used to describe the curriculum and organizational traits of schools that encourage the development of children's fundamental values in school (Yaumi, 2014).

Nautical is everything related to the sea and the ocean (Siswanto, 2018). It is everything that has to do with the sea (Pusat
Bahasa, 200. Nautical is inseparable from people who work at sea or shipping called sailors whose object is the sea. Nautical is closer to people who have a profession as sailors and meet their needs with daily activities at sea.

The activities of the life of the sailor community can not be separated from the character of the admiral who is famous and enshrined into the name of the school and others, namely an Admiral Hang Tuah. Hang Tuah was born in 1444 in Malacca and is the son of Hang Mahmud and Dang Merdu Wati. Since childhood, he has seen the fighter's soul and his spiritual concept because he worked as a logger in his parents' shop (Media, 2019). As someone famous for his courage, it is shown with his best friend when fighting rioters in his village (Schap, 2010). Over time Hang Tuah became an admiral and famous for his loyalty, as evidenced by becoming the sultan's trusted bodyguard (Media, 2019). And Hang Tuah is famous for being valiant, wise, and wise upstream, and straight and very loyal to his master (Schap, 2010).

Admiral Hang Tuah can be included in the subjects of Pancasila Education and Citizenship to form a religious character. Pancasila education and citizenship serve as a foundation in equipping students with character, science, and becoming good citizens (good citizens) (Lubis, 2020).

The essence of Pancasila Education is formed from the original identity of the 
Indonesian nation (Saputro, 2021). The essence of Civic Education is that it has three main functions as a vehicle for the development of democratic citizens, namely, developing civic intelligence, civic responsibility, and civic participation (Ikhtiarti, Adha, and Yanzi, 2019). I understood that the three main functions become essential to apply to the learning joints of Pancasila Education and Citizenship. These points become an absolute thing to be included in the learning of Pancasila Education and Citizenship (PPKn) at all levels of education, which is adjusted to the level of student understanding and knowledge capacity.

Students' understanding of learning outcomes is supported by learning media, including seen from several studies. After being given learning, students' learning outcomes are different and better than before, such as using pocket books and supported by score acquisition from validators showing the category is very valid and very positive so that mind mapping-based pocket books are practically worth using (Masita and Wulandari, 2018).

Based on the research results related to pocket books and which have been successfully piloted, pocket books can be used as a prototype of other models in developing educational and fun alternative learning and more accessible for students to understand.
The development of this pocket book consists of 5 (five) stages through (Bakhri, 2019), that is:

a. An analysis is the initial stage of development research by conducting curriculum analysis, student needs, PPKn subjects, and formulating objectives.

b. Design is the stage of designing pocket book media that will be developed in the form of a pocket book draft of the character of The Elderly Admiral Hang Tuah.

c. Development is the stage of producing products developed, starting from creating pocket books, research instruments, expert validation, and revision.

d. Implementation is a pocket book trial stage that has been said to be feasible by experts on the test subject.

e. Evaluation is a stage of measurement of the reach of the purpose of development research, namely the feasibility of pocket books as a learning medium.

The initial stage of this research was conducted to find problems that occurred in strengthening the values of nautical character in Junior High School Hang Tuah 4 Surabaya. The analysis starts from curriculum analysis, student needs analysis, and VAT subject analysis by conducting observations and interviews of PPKn Teachers. Based on observations and interviews that have been collected, it takes a learning medium that can increase students' reading interest. 
The next stage is to design the character education pocket book product Admiral Hang Tuah by the format of the preparation of the pocket book starting from the size, shape, preliminary section, the contents section to the closing. The pocket book that has been designed to design the product is set in the pocket book draft. The following designed pocket book is produced to be validated by material experts, linguists, and media experts. This validation activity aims to assess the feasibility of the media pocket book of the character education of admiral Hang Tuah which the input provided by experts developed. Once said worthy, the pocket book was developed further piloted to discover the advantages and disadvantages of book media from prospective users, namely students of class VII Junior High School Hang Tuah 4 Surabaya.

The primary purpose of developing Admiral Hang Tuah's character education pocket book is to assess the feasibility of admiral hang tuah's character education pocket book developed. The trial activity was conducted only once consisting of 15 students of class VII A Junior High School Hang Tuah 4 Surabaya. In the final stage, the evaluation stage, the researcher conducts an evaluation on the medical pocket book as a whole.

\section{Media Eligibility of Pocket Book Character}

\section{Education Admiral Hang Tuah}

The feasibility of pocket book media is assessed through the validation stage by 3 (three) validators. Validator selected by the researcher consists of Material Expert, namely Dra. Ni Putu Asti Arini, M.Pd. (a Teacher PPKn SMP Hang Tuah 4 Surabaya, as well as civil servants of the Lantamal V Surabaya Navy), Linguists are Dr. Mimas Ardhianti, M.Pd. (Lecturer of Faculty of Social Sciences and Humanities, PGRI Adi Buana University Surabaya), and Media Expert, Lecturer Nurissaidah Ulinnuha, M.Kom., from faculty of science and technology, Sunan Ampel State Islamic University Surabaya. The assessed eligibility aspect consists of content qualifications, language qualifications, presentation qualifications, and capability qualifications.

Validation results by material experts are done to find out the feasibility of the media in terms of its material. The aspect assessed is the aspect of content feasibility is the feasibility of the contents of the educational pocket book of the character of Admiral Hang Tuah reviewed from 8 points of statement assessed by material experts. Overall aspects of content eligibility earned an average score of 4.6, which belonged to the Category Very Decent.

Linguists' validation results are done to find out the feasibility in terms of language. The aspect assessed is the feasibility aspect of pocket book language from 6 items to process an average score of 3.8, which falls into the category of Decent. 
Validation results by media experts are done to find out the feasibility in terms of media. The aspect assessed is the aspect of the presentation, and radiography is the feasibility of the contents of the educational pocket book of the character of The Elderly Admiral Hang Tuah reviewed from the aspect of the presentation of the 5 points of the statement obtained 4.8 which fall into the category of very worthy. The pocket book graphing aspect of the 8 statement items earned an average score of 4.4, which falls into the Very Decent category.

Based on the overall results of the pocket book assessment, material experts, linguists, and media experts obtained a score of 4.4 , with a very decent category.

Student Assessment of The Pocket book of Character Education Of The Kebaharian Admiral Hang Tuah As a Learning Medium Of Students Class VII A Junior High School Hang Tuah 4 Surabaya is the subject of a trial of research products for the development of pocket book media. The student's response to the media eligibility assessment sheet aims to determine the feasibility of the pocket book in terms of the material and its media. Based on the results of pocket book validation, content feasibility, language, graphing to presentation shows the average score of 4.6, which belongs to the category is very feasible.

\section{CONCLUSION}

Based on the results of the study, first, the development of pocket book media of character education laksaman Hang Tuah Based PPKn through 5 (five) stages, namely: analysis, design, development, implementation, and evaluation.

Second, based on the feasibility of the media pocket book education of the character of the preserving Admiral Hang Tuah, the overall results of the pocket book assessment based on material experts, linguists, and media experts obtained a score of 4.4 with a very decent category. Based on the response of students of class VII Junior High School Hang Tuah 4 Surabaya with a pocket book shows an average score of 4.6 , which belongs to the category is very feasible.

\section{REFERENCES}

[1] Acetylena, Sita. (2018). Pendidikan Karakter Ki Hadjar Dewantara. Malang: Intrans.

[2] Aldoobie, Nada. (2015). "Technology Integration and Learning Theory." American International Journal of Contemporary Research 5(6):114-18.

[3] Bakhri, Syamsul. (2019). "Animasi Interaktif Pembelajaran Huruf Dan Angka Menggunakan Model ADDIE." INTENSIF: Jurnal Ilmiah Penelitian Dan Penerapan Teknologi Sistem Informasi 3(2):130-44.

[4] Fattah, Zulfikar Waliyuddin. (2020). "Pengembangan Model Pembelajaran Social Assimilation Project (SAP) Pada Matakuliah Pendidikan Pancasila Di Universitas Negeri Malang." Universitas Negeri Malang.

[5] Husain, Muhammad. (2015). "Pengembangan Bahan Ajar Buku Saku Pada Kompetensi Dasar Mengidentifikasi Definisi Dan Ruang Lingkup Sarana Dan Prasarana Kantor Pada Siswa Kelas XI APK 1 SMKN 1 Surabaya." Jurnal Pendidikan Administrasi Perkantoran (JPAP) 3(3). 
[6] Ikhtiarti, Endang, Muhammad Mona Adha, and Hermi Yanzi. (2019). "Membangun Generasi Muda Smart and Good Citizenship Melalui Pembelajaran PPKn Menghadapi Tantangan Revolusi Industri."

[7] Lubis, Maulana Arafat. (2020). Pembelajaran Pendidikan Pancasila Dan Kewarganegaraan:(PPKN) DI SD/MI: Peluang Dan Tantangan Di Era Industri 4.0. Prenada Media.

[8] Masita, Mariana, and Desi Wulandari. (2018). "Pengembangan Buku Saku Berbasis Mind Mapping Pada Pembelajaran IPA." Jurnal Kreatif: Jurnal Kependidikan Dasar 9(1).

[9] Media, Kompas Cyber. (2019). "Biografi Tokoh Dunia: Hang Tuah, Pahlawan dan Laksamana Malaka Halaman all." KOMPAS.com. Retrieved December 29, 2021 (https://internasional.kompas.com/read/2019 /03/12/21281801/biografi-tokoh-dunia-hangtuah-pahlawan-dan-laksamana-malaka).

[10] Purnamasari, Veryliana, and Muhammad Nur Wangid. (2016). "Pengembangan Perangkat Pembelajaran Berbasis Scientific Approach Untuk Membangun Karakter Kepedulian Dan Kedisiplinan." Jurnal Pendidikan Karakter 6(2).

[11] Pusat Bahasa. (2016). Kamus Besar Bahasa Indonesia Pusat Bahasa. Jakarta: Gramedia.

[12] Ricklefs, Merle Calvin. (2005). Sejarah Indonesia Modern, 1200-2004. Penerbit Serambi.

[13] Saputro, Aris. (2021). "Sociological Foundation of Pancasila Education as the Original Identity of Indonesian Society." JED (Journal of Etika Demokrasi) 6(1):45-53.

[14] Schap, Bot Genoot. (2010). Hikayat Hang Tuah II. Jakarta: Pusat Bahasa.

[15] Setyono, Yulian Adi. (2012). "Pengembangan Media Pembelajaran Fisika Berupa Buletin Dalam Bentuk Buku Saku Untuk Pembelajaran Fisika Kelas VIII Materi Gaya Ditinjau Dari Minat Baca Siswa.”
[16] Siswanto, Heni Waluyo. (2018). "Pendidikan Budaya Bahari Memperkuat Jati Diri Bangsa." Jurnal Pendidikan Ilmu Sosial 27(2):204-22.

[17] Sofyan, Asep. (2017). "Penanaman NilaiNilai Pendidikan Karakter Melalui Pembelajaran Seni Budaya (Sub Materi Musik) Pada Siswa Kelas VII SMP Negeri 2 Semarang Tahun Ajaran 2017/2018." Universitas Negeri Semarang.

[18] Sugiyono. (2015). Metode Penelitian Kuantitatif, Kualitatif, dan Kombinasi (Mixed Methods). Bandung: Alfabeta.

[19] Undang-Undang Nomor 20 Tahun (2003) tentang Sistem Pendidikan Nasional.

[20] Yani, Yanyan M., and Ian Montratama. (2018). "Indonesia Sebagai Poros Maritim Dunia: Suatu Tinjauan Geopolitik." Jurnal Pertahanan \& Bela Negara 5(2):25-52.

[21] Yaumi, Muhammad, (2014). Pendidikan Karakter: Landasan, Pilar dan Implementasi. Jakarta: Prenada Media Group.

[22] Zainal, Aqib, (2011). Pendidikan Karakter Membangun Perilaku Positif Anak Bangsa. Bandung: Yrama Widya. 